\title{
Practical Ways to Ensure Educational Justice for Subaltern Students of Nepal
}

\author{
Mahendra Kumar Karki ${ }^{1}$
}

mkarki123.mk@gmail.com

\begin{abstract}
This article aims at sharing knowledge about educational justice for subaltern students of Nepal. The descriptive research design was used for the study. The secondary sources of data were educational document and online materials. The sample was limited to the only concept educational justice for subaltern students of Nepal and global perspectives. With few exceptions, students of the subaltern community obtain low score in school, college, and university. The article applies to some theories like as cultural, ethical, and pedagogical. Research also mentions theoretical, philosophical, and practical ways to ensure educational justice to the subaltern students of Nepal. Education plays a vital role to being a subaltern. Subaltern students have no access to achieve the facilities and opportunities provided by the government because of their different causes and unequal distribution of resources. They are being subaltern because they have no more representation in schooling system. The data used in study is qualitative which are collected from educational philosophical and related to Subaltern textbook, journal and National and international educational report. Likewise, various an educational document, Ministry of Education Nepal. Analytical and descriptive methods are applied in this study.
\end{abstract}

Keywords: Subaltern, justice, marginalized community, postmodernism

1 Lecturer, Adarsha Multiple Campus

AMC Journal, Volume 1, Number 1 (2020) 


\section{Introduction}

In post -colonial studies and critical theory the term subaltern designates the colonial populations who are socially, politically and geographically outside the ranks of power of a colony. As a method of investigation and analysis of the political role of subaltern populations, Marx's theory of history presents colonial history from the perspective of the proletariat that who and what social class are determined through the economic relations among the social classes of society. A subaltern is someone with a low ranking in a social, political or other hierarchy. It can also mean someone has been marginalized or oppressed.

Gramsci (1934) used the term 'subaltern' to refer to those social groups subjected to the hegemony of the ruling classes in his time (p. 5). He used this term to cover a great variety of people, including peasants, workers and other groups having no access to hegemonic power. Similarly, Guha (1982) used the word 'subaltern' to denote the entire people that hold a subordinate position in term of class, caste, age, gender and office or in any other way (p. vii). This shows that the word subaltern indicated all kinds of people who are marginalized and subordinated.

The students of subaltern community also disqualified and marginalized both pedagogically as well as instructionally. As a result, student of subaltern community obtains low score in school, college, and university. The exception is there in the history of subaltern and it can be considered as episodic and fragment (Shrestha, 2010). The story of rare success of subaltern students is kept by the elitist for patronizing their works and history. The elite need the subaltern history for glorifying their works of history. Therefore, the subaltern students barred because of their right of education. They do not get opportunities in the school. The history launched opportunities to elite person and communities so that the children of the subaltern do not get any chance to extracurricular activities in the school. The subaltern student insured to the bad activities by other students.

Teachers often treat poor children differently from non-poor children. Their works, contributions, participations in the making histories are largely ignored and excluded by elite historiography and colonialism together (Ludden 1992). Many of the subaltern student's surmise from the elite's student and teacher. So the subaltern students are feeling and thinking diurnal and sustain because the family background is poor, disqualified and ignored by elite's family and communities. The existing education administration, ministry, university, college and school are elitists who are largely excluding subaltern students 
from education (Guha, 1982). The school and teacher are elitists who do not care about the subaltern children. As a result, they are left behind because school and teacher never perceive their perceptions.the school and teacher are elitists who do not care about the subaltern children. An observed 2.6 million Nepalese student between the ages of 5 and 14 are child labor. They are working in furniture industries as carpenter, brick factories as a labor and other danger areas. Because of Nepalese public schools generally charge administrative fees and other fees for books and exam fees as well as school uniforms. Struggling marginalized family like Dalit community cannot afford to educate their children. Many students are members of Nepalese marginalized and Dalit community. The school has made remarkable strides towards gender party in a country where in a country the education of girls is often not valued with equally with the education of boys.

\section{Literature review}

The word has a longer past, the late medieval English. Then, it applied to vassal and peasants. The term "subaltern" in this context is an allusion to the work of Italian Marxist Antonio Gramsci (1891-1937). It refers to any person or group of inferior rank and station, whether because of race, class, gender, sexual orientation, ethnicity, or religion. Antonio Gramsci (1891-1937) began to weave ideas about subaltern identity into theories of class struggle. Subaltern studies deployed some of Gramsci's ideas at a critical juncture in historical studies (Arnold 1984; Chopra 1982). The term subaltern is used in postcolonial theory. The exact meaning of the term in current philosophical and critical usage is disputed.

Many research have been studying about the subaltern over many years and proposed their theories on subaltern. Such theories study disclosed the contemporary societies, histories and cultures following bottom up approach. In academic sites are reflecting this trend, the 1993 edition of the new shorter Oxford English Dictionary' included 'history' of subalterns for the first time.

Subaltern studies joined debates about insurgency and nationality (Alam, 1983). The breach was at breach between popular unrest and state power. It is in this state the local self-governance Act (2011) of Nepal promised to "shift power away from central government and pass it to local people it to local people and community groups". And yet subaltern community does not have opportunities from the government. Only the elite community, who live in such a community, led them. 


\section{Objective of the study}

The specific objective is to analyze the practical ways to ensure educational justice for subaltern students of Nepal aggregate subaltern of different perspectives.

\section{Data sources and methods}

The data used in study is qualitative which are collected from educational philosophical and related to Subaltern textbook, journal and National and international educational report. Likewise, various an educational document, Ministry of Education Nepal. Analytical and descriptive methods are applied in this study.

\section{Result and discussion}

\section{Educational Justice for Subaltern Students Different Theoretical and Pedagogical Perspectives}

As we have discussed that subaltern students are bottom class students, I hereby attempt to see how the cultural, ethical and pedagogical theories say about the subaltern students. Jensen's biogenetic theory explains that the general cognitive skills are essentially inherited traits determined by the genetic factors than that of environment. These people are unprivileged in everything. They does not support by the elite because our society has two categories: haves and haves not .The haves are elite who are leading and guiding to the marginalized.

Subalterns are also minorities contemporary sociologists generally define the these minority group of people-differentiated from others in the same society by race, nationality, religion, or language, who both think of themselves as a differentiated group with negative connotations. Furthermore, they are relatively lacking power and hence are subjected to certain exclusions, discriminations, and other differential treatment. The important elements in this definition are a set of attitudes-those of group identification from within the group and those of prejudice from without -and set of behaviorsthose of self-segregation from within the group of people. The students of subaltern community also excluded and marginalized both pedagogically as well as instructionally. As a result, the student of subaltern community obtains low score in school, college, and university. 


\section{Pedagogical theory}

A theory knows as generalized statements related to experience, truth or behavior; pedagogy means educational terms that means educational teaching process. This term is new educational innovation in the teaching learning process of educational system. It could be said that pedagogy is the new orthodoxy in education. Numerous popular and best-selling textbooks bestow the virtue of 'getting the buggers to behave' (Cowley, 2003); 'managing classrooms' or behavior (Dixie, 2003; Rogers, 2006; Visser, 2000) and knowing 'how to teach' or indeed 'how not to teach' (Mr Read 2006), 'how to teach with a hangover' (Sedgwick, 2005) and providing ‘500 Tips for Teachers' (Brown et al., 1998). Increasingly, teacher-training courses focus less on subject disciplines and more on the discipline the educational change undergoing to the society. Here I would like to talk about the subaltern people and communities educational pedagogical situation of society.

The subaltern people is the unqualified of education and some people is illiterate. The school is far from these communities. The school environment for them is not favorable, so, the children are not interested to admit in the school. The people sheltered in the edge of the city and side of the river, they are far from the government attention. In another words, the government does not provide of the requirement of the human development. Due their low human development and poverty, they are not interested to send their children to a school. The school is taken as a miniature society where multicultural, multiethnic and multi dimensional children are admitted for the education. So, school represents different community, for incense, rich,poor and other categories student. The subaltern people feel own self presser for them everything

The teacher to take seriously the project of critical educational theorists to interrogate the wider social, the political and the public significance of pedagogy in terms of relations power and considerations of justice. Pedagogical modes of address are particularly useful in understanding contemporary change in the cultural practices of governing (Isin, 2004), state -citizen relations and governance (Newman, 2005). This is particularly significant in the context of the changing forms, agencies and rationalities of educational governance (Ball, 2007).

Hence, we could consider the state-citizen relation as essentially pedagogical - what Foucault might term being 'directed at positively governing conduct' 
the subaltern people and community has a need for directed focus for good education and increasing educational programmers to much more involve in education .

\section{Cultural theory}

The cultural capital is hierarchical ordering of knowledge-based system in school. It is socially ratified instrumental knowledge gifts and skills safeguard and nurtured by the upper and upper middle classes and used by them to maintain their hegemony in the society (Bourdieu \&Passeron, 1977). Similarly, Hall's theory of culture is, I think, based on assumptions that go hand in hand with Spivak's theoretical framework and the inter subjective attitude. He argues, "The only theory worth having is that which you have to fight off, not that which you speak with profound fluency" (Morley 1996, 265-6). Suggesting that there is a double play between resistance (holding on to what one thinks) and openness (letting the ideas have an impact on one's thinking) whenever one articulates a genuine theoretical stance. The theory of social active learner role risks and hidden of the curriculum, the classroom culture stress order. Subaltern peoples theoretically and practically marginalized. Our school curriculum gives emphasis on the Nepali language but our society is multi-lingual .Therefore, every subaltern people are surrounding to the Nepali language not other his/her language. No curriculum related language, related areas, related, culture and ethical working relationship ever designed. Subaltern peoples live in rural areas .There is a lack of requirement of human life and daily life. Therefore, recent changes in the nature of the family have important implications for children's educational development and success in school. Children poverty is a major problem for many families. Therefore, the discussion on the relationship between social class and educational achievement depends on social, race and school achievement. A large number of the children who have lost their parents during a ten-year-long maoist insurgency period in Nepal. Therefore, pressures on children housework, social work and lack of money that are the difficulties for obstacle of school, college and university education. It's my concern children from any social class may suffer abuse or neglect by their parents or other house members. There are many cases of neglect for clothes, food, medicine, education, entertainment and other requirement of leading a quality life (Ornstein \& Levine 2011, p. 213). Many child welfare agencies have been overburden by the extent of the problem. Although they work to keep families together for the safety of children, such agencies often must remove children from their homes and 
place them in foster care. Some of the students are homeless and parentless. According to Dockery, D. J. (2012). The homelessness and parentless are the major problems of the dropouts in school. In addition, the cases have been repeated in colleges and universities due to the lack of money and opportunities) School dropout indicators, trends, and interventions for school counselors.

Similarly, some schools have obtained fund from different sources as incentive programme, for example, girl's scholarship program, Dalit scholarship program, midday meal, etc. but they used such provisions in the wrong way. For example, Kalaiya of Bara district, school principal has taken the money for his own purpose. This money was obtained from Department of Education for students' midday meal (Gorkhapatra, 2010). Therefore, subaltern communities' students are also the subaltern from the government side. The government could not flow the own program.

Almost without exception, moral education through the folkways was authoritarian. Children learn folkway morality in the very act of being required to be obedient. The great advocate of teaching morality reflectively was Socrates (469-399). In the mind knowledge and virtue went hand in hand. The word ethics comes from the Greek ethos, meaning something like 'morals'. In fact, ethics defined as the systematic reflection on what is moral. In this definition morality is the whole of opinions, decisions and actions with which people express what they think is good or right. Therefore, in short, to think ethically, you need to systematically reflect on what people think is good or right. Ethics is not a manual with answers on how to act. It is only a search for the right kind of morality this ethical theory is emphasis that what the moral about subaltern is. Ethics is not static it is dynamic process and is situational.

In my opinion, education plays a vital role to being a subaltern. Subaltern students have no access to achieve the facilities and opportunities provided by the government because of their different causes and unequal distribution of resources. They are being subaltern because they have no more representation in schooling system. Hungry mind could not think about the right and responsibility of the nation and community, they can only think how to fulfill basic needs. The creative age is wasting being child labors and child worker. They are struggling for the fulfillment of their basic needs instead of schooling. They are feeling hesitation with their fellows in schools because after returning home, they go to help their parents in fellow's house where their parents are working. In addition, they

AMC Journal, Volume 1, Number 1 (2020) 
have no proper materials of schooling: sanitation, clothes so on. In spite of having strong desire in schooling subaltern children have compulsion to do the labor and work for the fulfillment of their basic needs. Therefore, they are unable to continue and progress their education. Thus, I can say that subaltern students have low achievement in school and university where dropout rate is also high. This is the main cause of poverty. They have to work in house hold works such as cow herding, cooking food, caring their younger brothers and sisters, working in fields, etc

\section{Religious theory}

According to this theory, religion is the main reason for the origin of caste (Hocart,1996 cited in Koirala,). A part of his theory states that contemporary religious beliefs are simply reproductions of past religious beliefs. Religiously knowledgeable people often view themselves as superior to non-religious people, who internalize this view and see themselves as inferior. Religiously active people are involved in ritualistic activities and claim themselves to be superior to others. Then social policy makers, through enacting rules and enforcing behaviors, codify unequal social relations.

They believe on the cultural values and norms because they are blind supporter on the religious. Fortunately, the means for overcoming this educational handicap were at hand (Bruacher, 1996 p.304).

\section{Marxist theory}

The Marxism theory refers to a school of economic thought. Its foundations to the critique of classical political economy, first expounded upon by Karl Marx and Friedric Engels (Andrew, \& Glyn, 1987). Economic status determined to the social situation of the people. The subaltern people and communities are political and economical backward in the society. For incenses, the subaltern people and communities are ignoring by elites groups. The subaltern groups are excluded from the history because do not write the history. The society has to divide to two group is haves and havesnot. The haves group is elites group and haves-not group is elite. Therefore the subaltern people is dominated and dislike by the elites people because the people is marginalized from the everything. The personal quality of individual separates rulers from the ruled. The elites owe their position to the superiority of their personal characteristics. The ruling minority and the ruled is inevitable in the society which merely result in the replacement

\footnotetext{
AMC Journal, Volume 1, Number 1 (2020)
} 
of own ruling elite by another. Haralambu (2009: 106) further said," Marx, proposes that power in capitalist society is monopolized by the bourgeoisie and only the way to end this monopoly is communal ownership."From Marian perspective, the bourgeoisie monopolizes power in capital society. The subaltern people and communities are backward and disqualify marginalized because they have no power and capital.

\section{Conflict theory}

My understanding, theconflict theory is a theoretical orientation emphasizing the opposition among individuals, groups or social structure. It is the conflict between superior or inferior power and marginalized groups. According to Mars (citer in Sharma, 2062:194) "The history of hither to existing society is the history of class struggle. Free man slave, patrician and plebeian, lord and serf, guild and journeyman in a word oppressor and oppressed, stood in constant opposition to another carried on an uninterrupted, now hidden, open fight.

To the conflict theory, Ritzer also (2000:209) said," conflict theory generally focuses on social structures; it has little or nothing to say about actors and their thoughts and action."It means actors and their thoughts aren't concerned in society. Raj Kumar's (2003; p:3) view is related to it. He said ,God didn't create man with the badge of superiority or inferiority." It is the personal qualities of individual of being superior or inferior, which is led by social structure. Here, woman, Dalits, janjatis, madhesi people are subaltern especially male are the power holder.

The subaltern groups are oriented differently such as socially aware by INGO/NGOS politically aware by political parties' caste, ethnic religious ethnologically aware by ethnic caste religious organization and hold different backup knowledge to raise the voice against power especially by Marxist orientation in conflict period. The class conflict and subaltern groups were assertive by Marxist. Abraham, in Frencis (2001:107) once said Marx views that the existence of different sociological classes is the continuous sources of inevitable conflict and changes in the social structure.

\section{Religious approach}

Our community has different religious approaches. In my concern, people believe on God. They help each other in happiness and unhappiness. Specially, the villager peoples are kinder than town people are. To many 
people, this means "a return to religion" Religion has generally lent stability to society (Mecer\&Carr1957p.460). A society, which is deeply religious, believes on God. Therefore, subaltern student also believe on religious norms and values. Therefore, school environment created by religious activities. The subaltern student are to do moral activities and school religious program, because other student also believe on God. Therefore, religious approach helps the subaltern student activities increasing in the classroom. Teaching values through schools must be neutral with respect to religious; they may play an active role with respect to teaching civic values and virtue.

\section{Social approach}

Society is mixture of the caste and ethnicity. According to Prithivi Narayan Shah "Nepal was a flower gardening land and four caste comparing thirty-six varans" may- be our country has a lot of caste then they lived in cooperate each other. According to Marxism, society has divide into two group haves and have not group people in the society. The subaltern community have not group of the people. They marginalized, disappear, disqualified and poor line student. The structural split between the elite and subaltern leads to specific and particular universalisms where the whole social body .The subaltern people are disconnected from the 'social organization' of group in society.(Guha,1990) The subaltern students do not get chance anyplace because they excluded by elites community. In the school also teacher has represent by elites community. Therefore, a few chances get opportunities in school and classroom. According to Marx "with the change of economic foundation the entire immense super structure is more or less equally transformed". (Sharma \& Sharma 2069, p 334). The subaltern people economically poor and weak but other group is bourgeois elite in community. Those are holding a lot of property. So that, how can we equal each other. It is a debatable question.

\section{Political approach}

Political system is holding all over the system of country. Education and politics are related each other. Politics has helped to fulfill of communities requirement. Political system is political activities, rules, values, custom and political behavior worked system is called politics. Power is a generalized facility or resources in the society. The idea of colonial state exercising 
domination without hegemony comes from the Gramscian understanding of the state into two realms-civil society and political society. (Guha, 1998) The two difference classes' people lived in the society. The one groups is elitist and other is poor groups the two difference group has every time debate in the society. The subaltern people struggle for living life. Élite are thinking how to use in; politics for subaltern group people. According to Max Weber, "power as his chance of a man or a number of men to realize their own will in a communal action even against the resistance of others who are participating in the action." (ibid) Power is, therefore, power over others. The subaltern cannot speak about their problems because they feel hegemony and disqualified. In educational system, also commend by elites person. The subaltern student cannot say about own problems to teachers and school administration. Anytime could not influenced education from politics. The government provide for subaltern student scholarship, free textbook school dress and other requirement for child. If subaltern could not provide educational incentive, we cannot get expectation of educational justice.

\section{Economic approach}

An extra imperfection of market economy is that it divides the entire society into two classes-the rich and poor, the owners (employers and employees) and workers, or haves and haves-not (Ahuja, 2004). These two classes always fight with each other because of the class their interests. There is always a struggle between those two distinct classes.

In my opinion, nowadays every community has a struggle within two groups: the subaltern community and elites groups. Elites groups are access on education because they have a lot of economy. Subaltern groups have no access on education because they have no money. The elite' people got a lot of skilled because they have educational access. The subaltern group of people got no skill because they have no access in education. Educated and trained workers are more efficient because they are capable of handling various machine, equipment, tools etc. in a better way ( Kyustoiyiannis, 1979). Skillful people earn money but none skillful people have earned money so that they could invest in education. Therefore, subalterns are emphasized economical and educational opportunities. Economic growth polices thus need to promote the social inclusion agenda. 


\section{Educational approach}

I want to discuss about the subaltern term is below status, disqualified opportunities less and power less people is called subaltern. Those type of people do not get education. They are doing work here and there. They have lack of time and economy. They are not coming to access of education. So that, they lack the access of management and integration in education for subaltern student. According to Koirala (2069) Translate version.

Child leaning center is necessary for us. Question is compulsory? Major? Which model we need? School model? House model? Mobile model? Uncontrolled model? There should be consensus among all the parties regarding the answer of these questions. If integrated all these models, there can be a Nepal model.

I agree with this statement because our country has geographical and cultural problems. The distance of one house to another house is far. Moreover, there are different languages and cultures. So we use and select this types of model of teaching. For example, the subaltern people work in factories. Therefore the subaltern students do not get chances to go to school. Those students need education. We can educate them by mobile school system. Similarly, we need reforms in school teaching system and classroom managements. Definitions and expectations of appropriate behavior are culturally influenced, and conflicts are likely to occur when teachers and students come from different cultural backgrounds (Weinstein, Tomlinson Clark \& Curran, 2004). There are different concepts and perspectives of teachers and the elite towards the students from subaltern communities. "The Classroom the management service is the social justice (Weinstein, Tomlinson-Clarke \& Curran 2004, p.27) ". School is the miniature society. There are various types of culture and custom norms. If the subaltern community's students have not come to school, we need to provide them with education in the community by the model of mobile school system. Worker group and minorities group community children should be with provided day care and nursery education so that children can be safe and, at the same time, parents can go to work. We will try to provide self-reliance, socialization and creativeness education for child. Another better idea is that the disabled, the minorities and the subaltern students should be educated considering the concept of inclusive education. 


\section{Conclusion}

The subaltern people are socially, politically, and geographically outside of the hegemonic power structure. In addition, person rendered without agency by his or her social or any other kinds of status, and 'others" silenced 'or voiceless spivak the first used in a non-military sense by Gramci always hegemonic in the sense of the people those have not written history and any living place. For example, our dalit communities have many traditional skills but now these skills are not in the village. so that these skills should be promoted and developed for new generation. Documentation of these skills in the country is a historical problem. The subaltern people are janjaati, dalit also women as well as geographically poor and marginalized. Moreover, they have not got opportunities from the government. There are lacks of guidelines and leadership. Technically and practically people are struggle whole life but they have not linkage of the upper class family and politics. The subaltern people are saying about the life "No need to survive Nepal's changed political context does not accept it and there are many instances for the development of the peoplein the world" I agreed that quotation because the people are saying own views because rich people do not know how to live life Poverty.

The people are countless in the society. The subalterns' people are dominated by the cultural, political, pedagogical and historical perspectives. The subaltern people could not speak about their histories and identification. Indigenous and women focus on studies for that group. How to change those types of people they make plan and wrote an article and publications?Indian people and the country British government colonized. that was time that was in western country lived for studies they united and start to write for subaltern communities and people. Now a day the subaltern studies a synonymous for over the entire world scholar, educational and social institution.

\section{References}

Ahuja, H.L. (2004). Advanced economic theory. Rinehart \& Company, Ines: New York.

Allan C.Orenstein\&Daniel U.Levine (2008). Foundation of Education. Houghton Mifflin Company Boston:New York

Andrew Glyn (1987). "Marxist economics," The New Palgrave: A Dictionary of Economics,v. 3, pp. 390-95.

Ball, S. J. (2007),Education Plc. Understanding Private Sector Participation in Public Sector 
Education. Abingdon: Rutledge.

Brown, S., McDowell, L. and Race, PP. (1998).500 Tips for Teachers. London: RutledgeFalme.

Chakrabarty,D,(1989).Rethinking Working-class History Bangal 1890-1940 :U.S.A Princeton University press

Chatterjee. P, (2009). The small voice of History: RanajitGhua. New Delhi: Permanent Black

CherijeeveSharma\&Nirmal Sharma (2069). Sociological and Foundation Education Kathmandu,Nepal: M.K.publication

Cowley, S. (2003).Getting the Buggers to Behave 2. London: Continuum

Dockery, D. J. (2012). School dropout indicators, trends, and interventions for school counselors. School Counseling, p. 1-33

David Ludden ( $2^{\text {nd }}$ ed).(2005).Reading Subaltern studies. Permanent Black D-28: Oxford Apartments 11,1p.Extension Delhi 110092

Dixie, G. (2003). Managing Your Classroom and Classmates. London: Continuum. Rogers,

Fuchs,Stephen. (1984).The cultural and Religious Dimensions of Neo-Hinduism update Vol.8,No 1,pp-9-5

Haralambos M. Michael. (2009).Sociology Theme and perspectives. New Delhi: Oxford University Press

Isin, E. F. (2004).The neurotic citizen. Citizenship Studies, 8(p, 3), 217-35.

Kader BhakataMathema\&Min BahadurBist.( 2006). Ministry of Education and Sports Education Sector Advisory Team: Ministry of Kathmandu publication

Kyustoyinnis, A. (1979).Modern Micro Economics 2nd ed. (Macmillan)

New Delhi: Chand \& Company

Ranajit, Guha.(2005). Subaltern Studies V, Writing on South Asian History and Society. Oxford University press: New Delhi

Rizter George. (2000).Sociological Theory .Sing pour: M.C. Grew- Hill:international Edition

Rj Kumar.(2003). Essay on Dalits. New Delhi: Discovery Publishing House.

Sedgwick, F. (2005).How to Teach with a Hangover: A Practical Guide Overcoming Classroom Crises (Continuum Practical Teaching Guides). London: Continuum International Publishing Group.

Sholukhambupukar. (2069). Nepali Congress Sholukhumbu .Kathmandu Committees: Kathmandu, Nepal

Contact

Visser, J. (2000).Managing Behavior in Classrooms. London: David Fulton Publishers Ltd.

Newman, J., ed. (2005) .Remaking governance. Peoples, Politics and the Publics Sphere. Bristol: The Policy Press. 